\title{
Development of modernization tools for construction complex through the mechanisms of enforcement
}

\author{
Natalya Yaskova ${ }^{1}$, and Tatyana Alexeeva, \\ ${ }^{1}$ Moscow State University of Civil Engineering, 129337 Yaroslavskoe shosse 26, Moscow, Russia
}

\begin{abstract}
The article focuses on increasing potential of leasing as part of institutional approach to national economy innovative development. The mechanisms of leasing relations enforcement are examined. The structure of leasing relations institutions in the context of the specification of leasing participants' rights are researched. The authors highlight the features of leasing agents interaction, and on this basis justify the need for change in leasing relations institutional structure. Engineering institute implementation in the institutional system of leasing is proposed in the article. It will contribute to harmonization of leasing relations agents' interests, prevention of their opportunistic behavior, leasing participants transaction costs reduction and improvement of leasing relations enforcement.
\end{abstract}

\section{Introduction}

One of the national economy priority tasks (including construction complex) is the movement towards innovation-based development. Elaboration and introduction of innovations in construction sphere will enhance the quality of construction products, improve its technical characteristics and consumer features, ensure environmental safety and energy saving. The problem of Russian economy movement towards a new path of development is reflected in the works of many scientists [1-14]. Experts say that engineering plays an important role as an effective mechanism of its modernization. It is a complex of research, productive services, including the preparation of investments analyses, recommendations on production management and development of innovation activity of organizations etc. These services are provided by engineering companies [1-5, 7].

Previous studies of the authors have shown that in times of crisis and sanctions it is worth using leasing technologies to ensure innovative development of construction complex [1-4, 7, 11-13].

In the Russian Federation leasing is mainly used as a necessary property acquisition mechanism aimed at the development of production and economic process and tax optimization. Current state of leasing relations development showed that leasing

\footnotetext{
*Corresponding author: w220@yandex.ru
} 
mechanism needs improvement in order to fully realize its potential to intensify innovative development of construction complex and national economy as a whole.

For better understanding of construction complex innovative development characteristics, leasing relations specific features and engineering activity it is necessary to use institutional approach. A lot of scientists comment on this problem [1, 5, 6, 8-10, 12]. From the institutional approach viewpoint the concept of "institution" is defined as "rules of the game" in society, serving as certain restraining factors that organize and structure the relationship among economic agents. Institutions include formal regulations (laws, president decrees, codes, etc.), informal rules (traditions, social norms, stereotypes, etc.) and their enforcement mechanisms, which consist of the police, tribunals, public reprimand, etc. The complex of institutions forms institutional social environment [5]. L. Davis and D. North analyze it as macroeconomic level relations and as institutional framework that restricts contracting parties' terms of agreements. The complex of interrelated institutions represents institutional system [10]. In the system of institutions proper performance of established rules under condition of economic agents relations inconsistency can be provided by enforcement. This term means certain measure or condition directed to compulsion of parties to fulfill their contractual obligations. Enforcement through compulsion of economic agents to follow rules and perform obligations provides for their rights being fully realized, ensures respect of these rights, creates the incentive to act in good faith and thus stabilizes social and economic relations in Russia.

\section{Development of modernization tools for construction complex}

Different mechanisms of enforcement exist in practice. Among them are: state enforcement, group enforcement, self enforcement. State enforcement is realized by the establishment of legislative and administrative control on property rights regulations. Judiciary in its turn resolve disputes among economic agents.

Group enforcement is based on certain benefits from economic agents' participation in group relations and negative consequences in case of acting in bad faith. Self enforcement exists in relations where one partner is very interested in fulfillment of contractual obligations and the other partner realizes it. The possibility of loss of a trade partner in some cases can be sufficient for proper execution of obligations.

The framework of institutional theory and distinctive features of enforcement form the basis for research of the leasing relationships system in construction.

Federal legislation of the Russian Federation gives the definition of leasing: the complex of economic and legal relations arising from leasing contract including purchase of its subject (buildings, facilities, equipment, transportation, etc.) [19]. Among the advantages of leasing are the possibility of property purchase despite the lack of finance, taxes economy, decrease of innovation development risk, etc.

Leasing is the set of formal and informal rules and mechanisms aimed at enforcement of these rules (the institute of property, financial lease, crediting, insurance, etc), ensuring the regulation of economic and financial relations arising from the purchase of property and its further transfer for a certain term and fee [1].

The above mentioned rules and norms are necessary for stability and certainty of relations between leasing agents and defense of their rights and financial interests.

Formal institutions of leasing relations consist of legislative and legal regulatory acts in this sphere. Public relations traditions of different regions leasing markets serve as informal institutions. Production specialization of different regions influences the choice of the leasing subject and the tradition of public relations at the regional leasing markets.

The lessor, the lessee, the seller and other participants of leasing are the agents of leasing relations and their interaction is a process consisting of certain stages. At the first 
stage a future lessee chooses the seller of leased assets and the lessor. Then he draws an application for funding and sent it to the lessor. In case of positive decision after examination of all required documents on the financing of the leasing transaction lease agreement is entered into. In case of insufficient amount of lessor's funds to finance the deal he may apply to the bank for necessary credit resources. Lease contract is accompanied by sales contract concluded between the lessor and the seller of the leased assets. The next stage of leasing relations - is assignement of leased assets for use of the lessee. At the same time leasing object insurance is carried out to avoid various property risks. By mutual agreement of leasing transaction both parties (the lessor and the lessee) may act as the insured party. Thus leasing includes relations arising from finance leases, lending, sale and purchase of property, etc. Therefore formal leasing relations institutions include institutions of property, finance leases, credit relations and other institutions of market economy. In the system of leasing relations institutions the performance of established formal and informal rules and regulations under the conditions of contradictory interests of economic agents of leasing is provided by enforcement which is also an essential element of specification of leasing participants' rights, largely determining the leasing contract parties' negotiating positions and other conditions accompanying leasing deal. Thus, the specification of leasing participants' rights should be implemented at the level of the institutional environment and contractual relations. The institutional environment determines exclusiveness regime, that is a set of rights of leasing relations participants, later secured by lease agreement and other agreements accompanying lease deal. It also defines a further opportunity to protect the interests and rights of each of the leasing relations participants. In practice, there could be the institutional environment in which the functioning of formal enforcement is hindired or, on the contrary, it can contribute to its proper functioning. Available studies show that institutional environment which was developed in our country is characterized by instability and backwardness of many of its elements [9].

Let us consider the institutional environment of leasing relations, defining substantial characteristics of leasing participants' rights specification. One of the formal institutions of leasing relations is the institution of property, based on property rights, which represents authorized relationships between economic agents regarding the use of limited resources [5]. Proper execution of the established rules by economic agents is proved by enforcement of property rights. In the leasing relationships the leasing assets property right pertains to the lessor, which gives him certain powers: the right to earn profits, the right to transfer authority to another person, and others. At the end of leasing term ownership rights can be modified when property after full depreciation is transferred to the lessee's ownership at depreciated zero value. Leasing allows determining the object of property rights, actors, scope of their powers and the mechanism ensuring its compliance - all contribute to the creation of a stable economic environment and stable profit from leasing transaction.

Formal leasing relations institutions also include the institution of financial lease: the interaction of the lessor as the property owner and the lessee as the property user. The lessor receives revenue by leasing his own property and the lessee - from the use of the property in production and business activities, and at the same time the latter has the chance to avoid large one-time costs for the acquisition of property.

If the lessor lacks own funds for the purchase of property to be transferred to lease, he may apply to the bank, and in this case, the interaction between the lessor and the bank will be regulated by formal rules governing the relations of economic agents in the sphere of crediting. The specification of the lessor's rights (who is acting as the borrower) within enforcement mechanisms, is determined by formal rules in the sphere of crediting.

In the framework of other institutions operating in the system of leasing relations related contracts necessary to implement the leasing transaction are usually entered into. Formal enforcement of such contracts is established by the relevant terms and regulations. 
In business practice formal and informal institutions can complement each other, but contradictions can also arise. Consequently, for the development of leasing relations and their effective implementation in the context of innovation it is necessary to eliminate the inconsistency of institutions. Harmonization of these institutions can be achieved only by combination of leasing agents interests. The analysis has shown the lessee is interested in the possibility of reducing the initial costs of necessary equipment, machinery and other property purchase, receiving income from the leased assets operation, tax saving and other economic benefits. The lessor in his turn is interested in the receipt of income from leasing property under lease agreement, tax saving and other economic benefits. Interests of the seller of leased assets include benefit from products realization using leasing technologies, profit from ensuring technical maintenance of leased assets, and others. Leasing relations agents pursuing their economic interests is inclined to demonstrate opportunistic behavior. For example the lessor in course of transactions seeks to inflate the size of the commission, to hide the calculation mechanism of lease payments sums. The lessee strives to reduce the amount of lease payments by inclusion into leasing contract more favorable lease payment schedule, etc. The lack of information provided to leasing agents leads to certain difficulties in economic decision making. Participants of leasing relations obtaining more information enjoy certain advantages in the justification of leasing transaction. In the absence of sufficient information and qualification, potential lessees is unable to determine which equipment or machinery they need for the development of innovation activity and to assess the quality of property, which is supposed to be purchased, the amount of lease payments, to develop an effective leasing scheme, select a vendor, lessor, insurance company, etc. It is also difficult for the lessor to assess potencial risk of non-payment.

Taking into consideration the aforesaid, we propose to modify the structure of leasing relations institutions. The institute that will harmonize leasing relations, reduce risks and transaction costs, improve enforcement is really necessary. According to the research the institute of engineering is expected to perform all these functions. That is a set of rules, norms and mechanism of enforcement which regulate the engineering relationships aimed at ensuring stability, certainty and protection of participants' economic rights and interests [1]. Services of engineering companies include technical, technological audit of organizations (potential lessees), efficient and competent justification of equipment that is needed for innovation activities development, determination of the need for technological change and development of a project for modernization and innovation \& technological reequipment of construction complex organizations. As part of this project engineering companies will be able to develop an effective scheme of its financing. On mutually beneficial conditions these companies will ensure the selection of leasing assets provider, the lessor and insurance company, help in the process of leasing transaction support, etc.

\section{Conclusions}

In the Russian Federation as practice shows engineering companies often collaborate with particular leasing company, which provides services for projects financing, such as construction of small power plants (Mini-TES). The lessor traditionally carries out the process of development lease financing schemes and leasing management. We propose a new concept, according to which lease management is carried out by engineering company developing a project "turn-key".

In this concept the lessor preserves the functions of purchase and transfer of property to leasing, whereas the function of lease assets selection, its seller, insurance company and the lessor is transferred to engineering company. Therefore rights and obligations related to the implementation of these functions are conferred on engineering company. It also provides risk management services, advisory services on the conclusion of lease and related 
contracts. While operating leased assets engineering companies monitor lease payments, organization of technical maintenance of leased assets, training of lessee-company personnel, etc.

Modifications in the structure of leasing relations institutions and introduction of «engineering institute» allow forming one of the most effective management mechanisms of national economy modernization - "innovative leasing engineering" and create a new concept of leasing management [1]. This concept envisages leasing management services performed by engineering companies in practice, aimed at harmonization of leasing agents relationships, prevention of their opportunistic behavior, risk avoidance, leasing participants transaction costs reduction, improvement of leasing relations enforcement and innovative activities development. Practical application of the new concept proposed by the authors will help to prevent economic crises in the Russian Federation and ensure national economy movement toward innovative way of development.

\section{References}

1. T.P. Alekseeva, N.Y. Yaskova, Bulletin of Moscow State Construction University, 2, 146-158 (2016)

2. M.I. Kamenetskii, N.Y. Yaskova, Studies on Russian Economic Development, 26(2), 124-131 (2015)

3. T.R. Alekseeva, Bulletin of Moscow State Construction University, 1, 170-180 (2016)

4. T.R. Alekseeva, Economy and Business, 4-2(57-2), 583-590 (2015)

5. T.R. Alekseeva, Bulletin of Moscow State Construction University, 5, $152-161$ (2014)

6. A.A. Auzan, Institutional Economics: A New Institutional Economic Theory (Infra-M, Moscow, 2011)

7. V.I. Bazhenova, Problems of Economics and Law, 12, 16-23 (2011)

8. E.E. Ermolaev, R.A. Durov, S.Y. Kopelchuk, D.N. Silka, Engineering of investment and construction projects for industrial use. Monograph (Stroyinformizdat, Moscow, 2014)

9. K.A. Krutchankova, T.I. Buchtiyarova, Basic Research, 6, 1485 - 1492 (2013)

10. J. Ćetković, S. Rutešić, M. Zarković, M. Knežević, , N.Vatin, Procedia Engineering, 117 (1), 780-790 (2015)

11. S. Rutešić, J. Ćetković, M. Žarcković, M. Knežević, N. Vatin, Procedia Engineering, 117 (1), 905-915 (2015)

12. S. Rutešić, J. Ćetković, M. Knežević, M. Žarcković, N. Vatin, Procedia Engineering, 117(1), 642-650 (2015)

13. M. Knežević, Journal of Applied Engineering Science, 10(1), (2012)

14. M. Jocovic, B. Melovic, N. Vatin, V. Murgul, Applied Mechanics and Materials, 678, 644-647 (2014) 